\title{
Human envenomations caused by Portuguese man-of-war (Physalia physalis) in urban beaches of São Luis City, Maranhão State, Northeast Coast of Brazil
}

\author{
Denise Maria Ramalho Ferreira Bastos ${ }^{[1]}$, Vidal Haddad Júnior ${ }^{[2]}$ \\ and Jorge Luiz Silva Nunes ${ }^{[3]}$
}

\begin{abstract}
[1]. Programa de Pós-Graduação em Saúde e Ambiente, Universidade Federal do Maranhão, São Luis, Maranhão, Brasil.
[2]. Departamento de Dermatologia. Faculdade de Medicina de Botucatu, Universidade Estadual Paulista Júlio de Mesquita Filho, Botucatu, São Paulo, Brasil. [3]. Departamento de Oceanografia e Limnologia, Universidade Federal do Maranhão, São Luis, Maranhão, Brasil.
\end{abstract}

\begin{abstract}
Introduction: The clinical and epidemiological aspects associated with Portuguese man-of-war envenomation were investigated and characterized. Methods: Data from recorded envenomation events between 2005 and 2013 were provided by the GBMar (Group of Firemen Maritime of Maranhão State) and SEMUSC (Municipal Secretary of Security with Citizenship). Results: Most victims were children, and clinical manifestations included intense pain, edema, erythema, and rare systemic manifestations. Conclusions: The envenomation events were predictable and based on patterns involving multiple factors (environmental and/ or human behavior); however, the initially applied measures did not match the current recommendations of the Health Ministry of Brazil.
\end{abstract}

Keywords: Dangerous marine animals. Cnidarians. Bites and stings.

The leisure and work aquatic activities performed along the Brazilian coasts have led to frequent injuries caused by marine organisms ${ }^{1}$. The growing presence of humans in aquatic environments has increased the probability of contact with these organisms, as well as increased risks of trauma and envenomation ${ }^{1,2}$. Additionally, studies have shown that the injuries were mostly incurred by more vulnerable individuals and were mainly attributed to a lack of information or complete unawareness about these organisms ${ }^{2}$.

In Brazil, injuries caused by marine animals are considered a public health issue, given the number and severity of envenomation cases ${ }^{1}$. These injuries can cause sequelae such as temporary or definite disability and, in some cases, death ${ }^{3}$. Injuries caused by cnidarians, particularly the Portuguese manof-war (Physalia physalis), frequently affect beachgoers along the northeastern coast ${ }^{1,2}$. The frequency of envenomation varies throughout the year, as higher numbers of cnidarian colonies are able to reach the beaches in some months ${ }^{1,3}$.

The Portuguese man-of-war is a colonial organism that belongs to the Phylum Cnidaria. Its main features are the

\footnotetext{
Corresponding author: Dr. Vidal Haddad Júnior.

e-mail: haddadjr@fmb.unesp.br

Received 5 July 2016

Accepted 24 November 2016
}

presence of a gas bladder, or pneumatophore, and several tentacles comprising typical cell populations with different functions (dactylozooid, gastrozooid, and gonozooid). Morphologically, the Portuguese man-of-war exhibits vibrant coloring that may vary from green to lilac ${ }^{4}$.

Cnidarians are feared because they possess cnidocytes, or special defense and attack cells. These sophisticated cells feature an apparatus for venom inoculation, the cnidas (especially nematocysts). The venom comprises a complex mix of toxic polypeptides and high-molecular-weight enzymes, including methyl-ammonium hydroxide, serotonin, and histamine ${ }^{5}$.

In human beings, typical lesions that arise immediately after contact with a Portuguese man-of-war (i.e., while still in the water) include linear plaques with an urticariform aspect, due to edema and erythema, and excruciating pain. In some cases, envenomation can induce systemic manifestations such as nausea and vomiting, cold sweating, cardiac arrhythmia, syncope, and death. In addition, allergic responses to venom may manifest as anaphylactic shock, leading to death within minutes ${ }^{6,7,8,9}$. The above-described risks and global spread of this species have led to its designation as a public health issue worldwide ${ }^{1}$. Envenomation outbreaks have already been registered in Australia, Chile, Portugal, Spain, and New Zealand $^{10}$. In Brazil, outbreaks have been observed in the States of Rio Grande do Sul, Paraná, São Paulo, Rio de Janeiro, Pernambuco, and Maranhão $0^{1,2,11}$. 
Given the importance of this issue in our region, the present study aimed to investigate and characterize the aspects that comprise registered Portuguese man-of-war envenomation events in São Luis. This study used data provided by the Lifeguard Troops of Group of Firemen Maritime of Maranhão State (GBMar) and Municipal Secretary of Security with Citizenship of Maranhão State [Secretaria Municipal de Segurança com Cidadania (SEMUSC)] to analyze reported Portuguese man-of-war injuries that occurred from 2005 to 2013 on the most popular beaches in São Luis (Figure 1A), which is located on Maranhão Island and serves as the Maranhão State capital. These data were cross-referenced with treatment records from the GBMar for events reported at Calhau, São Marcos, and Araçagy beaches, and from SEMUSC for events reported at the Olho d'Água and Ponta d'Areia beaches. Data from 2007 were unavailable because of technical and operational problems, and only GBMar held registers from 2005 to 2006 .

The Physalia Project created a protocol to obtain man-of war envenomation data, which GBMar applied to their detailed information. Here, we only considered more complete injury data [e.g., age, body region, number of envenomations per individual, emergency care, lesion characteristics (Figure 1B), and symptoms] in 2013. A total of 89 registered Portuguese manof-war envenomation events occurred during the study period and were subjected to a descriptive statistical analysis involving annual and monthly comparisons. Other protocol descriptions were implemented to organize quantitative data, followed by comparison using percentage graphs.
According to general data obtained from GBMar and SEMUSC, between 2005 and 2013, 1800 Portuguese man-ofwar envenomation events were registered along the coast of São Luis City (Figure 1C).

Figure 2A illustrates a comparison of the numbers of envenomation events during this period. Increasing numbers of events were registered between December and January throughout the study period. In addition, the number of accidents appeared to increase from June to December, before decreasing at the end of January (Figure 2B).

The majority of injuries occurred during the afternoon. Nearly $73 \%$ of the injuries registered at Calhau and São Marcos beaches in 2013 occurred during high tide. Figure 2C illustrates the main circumstances related to the envenomations. Most cases occurred during bathing (55\%), followed by intended contact with cnidarians (i.e., touching) precipitated by bathers' curiosity (20\%). Individuals with ages ranging from 1-10 and 11-20 years tended to incur injury (Figure 2D) because of a lack of attention to and information about the animals. An aggravating factor was reported among victims with ages ranging from 31-60 years: treatment precipitated new envenomations, as self-contact with the injured regions allowed the further transfer of stinging cells (Figure 2D).

The most frequently injured body regions were the legs (23\%), hands (21\%), arms (17\%), and abdomen (12.5\%) (Figure 3A). All victims reported injuries over several regions of the body (Figure 3B). In most cases ( $80 \%$ ), victims presented with erythema and edema in linear plaques. Vesicles were observed

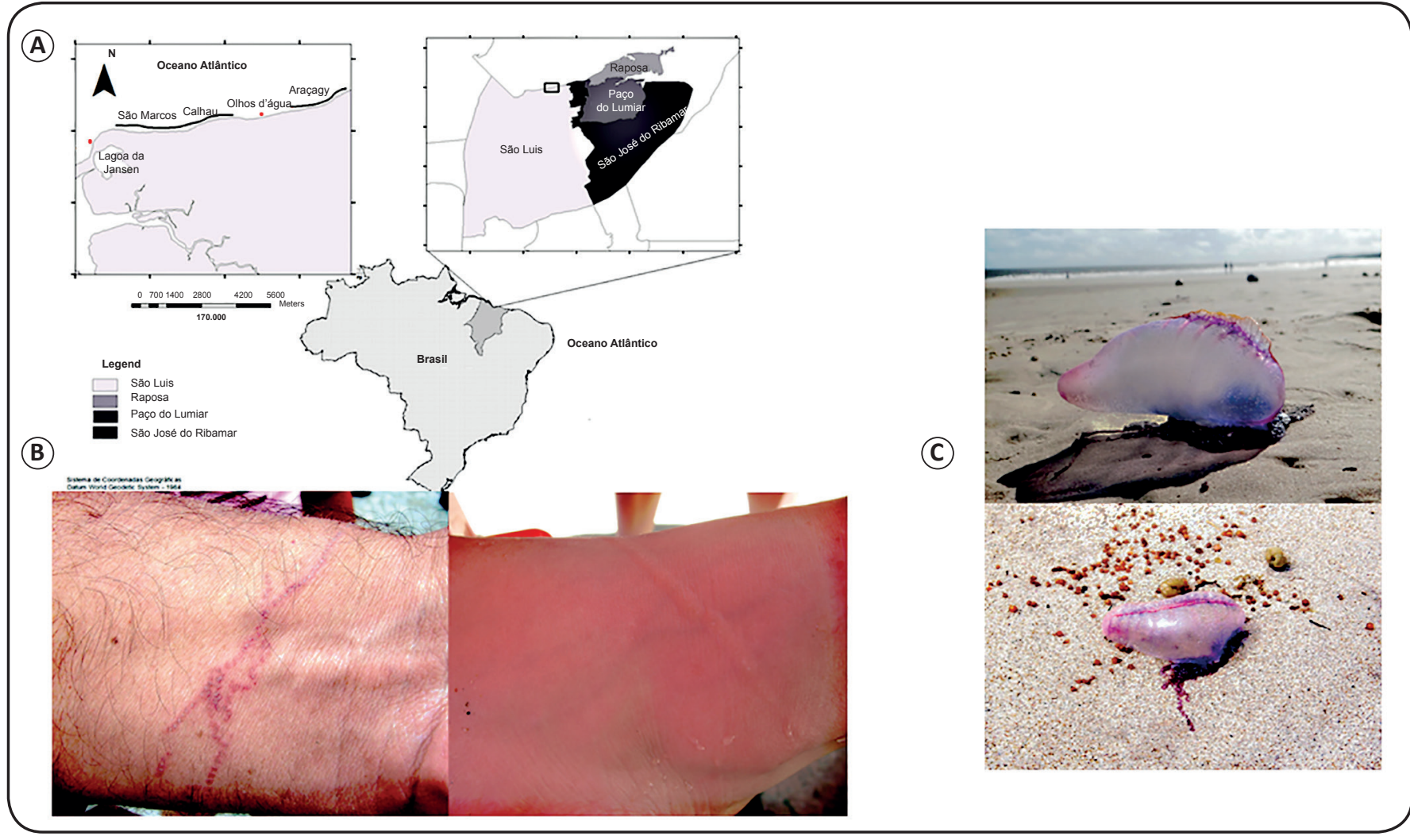

FIGURE 1. (A) Urban beaches monitored in this study. (B) Common lesion types. (C) Portuguese man-of-war specimens found on urban beaches. 
(A)
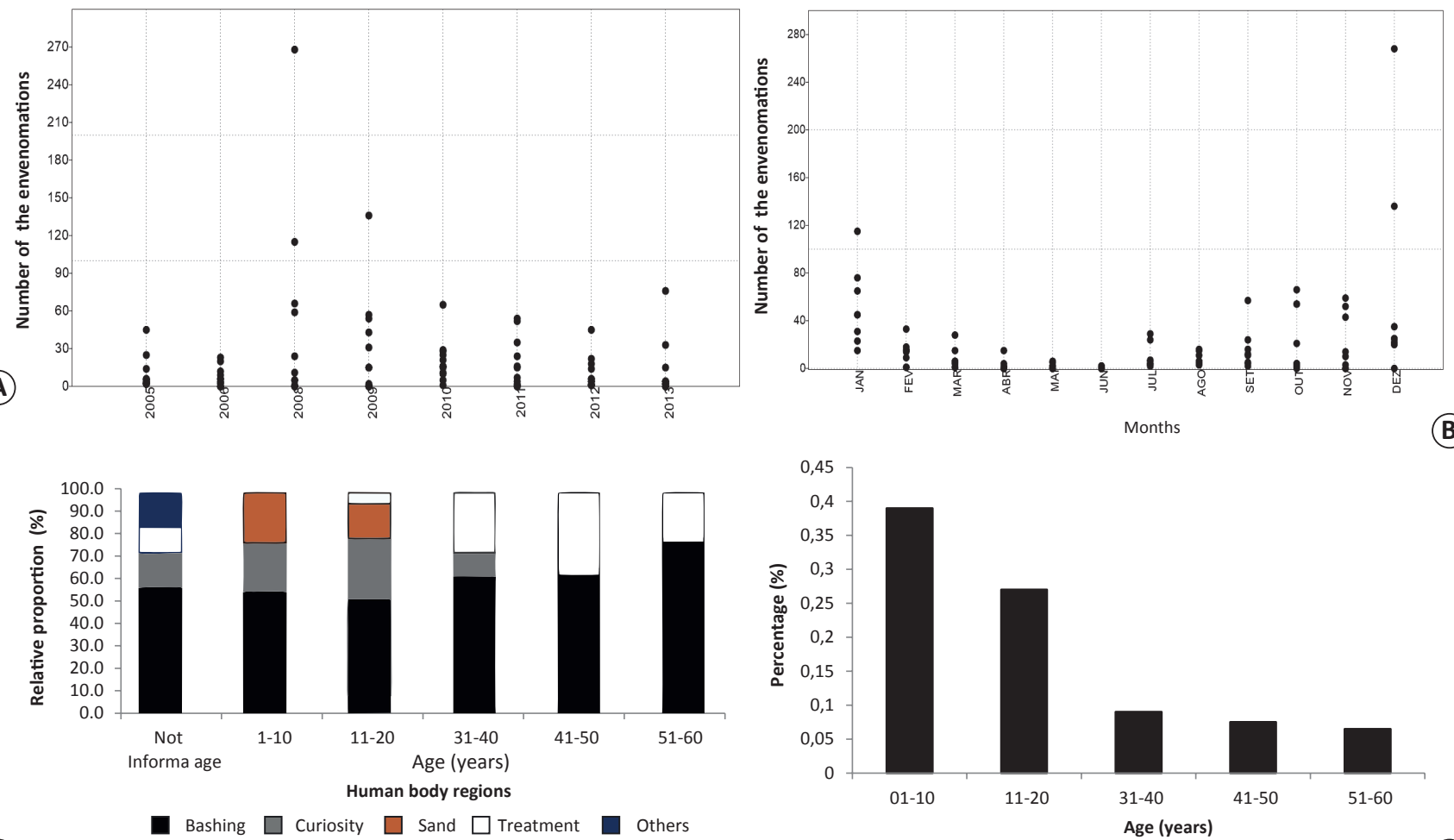

FIGURE 2. (A) Number of Portuguese man-of-war envenomations at the urban beaches of São Luis between 2005 and 2013. (B) Temporal distribution of envenomation events between 2005 and 2013. (C) Circumstances of envenomation by age between January and May 2013. (D) Number of envenomation events by age, between January and May 2013.

in some cases (16\%). Figure 3C shows that the most commonly reported symptom was pain and/or burning at the point of contact (46\%), followed by malaise $(10 \%)$ and dyspnea (8\%). Other symptoms included irritation, anxiety, and palpitation; these were present in nearly $14 \%$ of cases. One person developed shock and was registered at Calhau lifesaving station during treatment; however, this case was not registered by a medical team. Regarding treatment, lifeguards most frequently applied vinegar (acetic acid) and sulfadiazine. None of the victims reported washing of the affected areas with freshwater (Figure 3D).

Portuguese man-of-war envenomation is a serious issue for beachgoers along the coast of São Luis City; however, this issue is not on authorities' radar, despite the requirement of notification. Such events have been observed annually in specific months, especially during the summer and school holidays. Recent studies have shown a correlation between the presence of cnidarians and global warming ${ }^{5,12}$. In 2008, São Luis registered its highest ever number of envenomations. According to Gonzalez et al. ${ }^{13}$, the El Niño/La Niña phenomenon in 2007 and 2008 contributed to changes in rainfall and oceanic characteristics in Northern and Northeastern South America, and might have correlated with the increased number of cnidarian injuries in São Luis during this period. The Portuguese man-ofwar depends on both sea and wind currents for locomotion, a feature that might explain the increased presence of cnidarians during these years of shifting climatic phenomena, when the colonies are dragged into shallower waters.

New official appraisals of bathing conditions in mid-2012 led to the consideration of some beaches as completely or partly appropriate for bathing. This designation might have contributed to the increase in Portuguese man-of-war envenomation events during 2013, which occurred predominately at times when abundant numbers of cnidarians were likely available (i.e., high tide and afternoon; JLSN: personal communication, 2015).

This study observed a predominance of victims aged 0-20 years, and found that children were envenomed while bathing or by cnidarians on the sand. These findings serve as an important indicator that must be considered when designing preventive strategies. Neves et al. ${ }^{2}$ considered the curiosity of children to be a possible factor related to envenomation, as cnidocytes remain active even after the animal has died ${ }^{11}$. A lack of information about the dangers of contact with these animals might have increased the risk of envenomation ${ }^{8,11}$.

The circumstances of these injuries were also linked to bathers' curiosity and inobservance of risks when entering the sea. Some victims encountered cnidarians when helping bathers who had suffered injuries or when touching a victim's injuries. In other cases, victims (especially children) were injured while playing or 
(A)

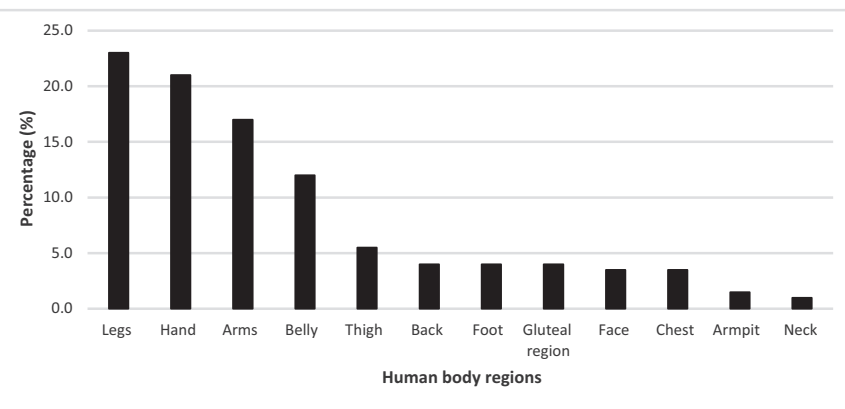

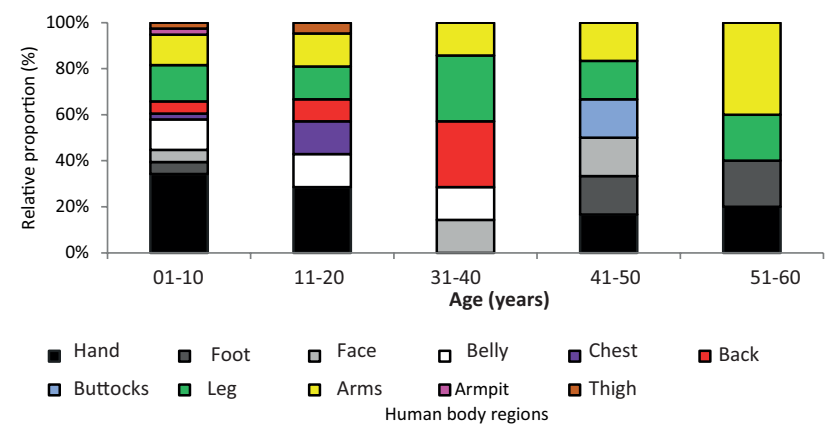

Human body regions

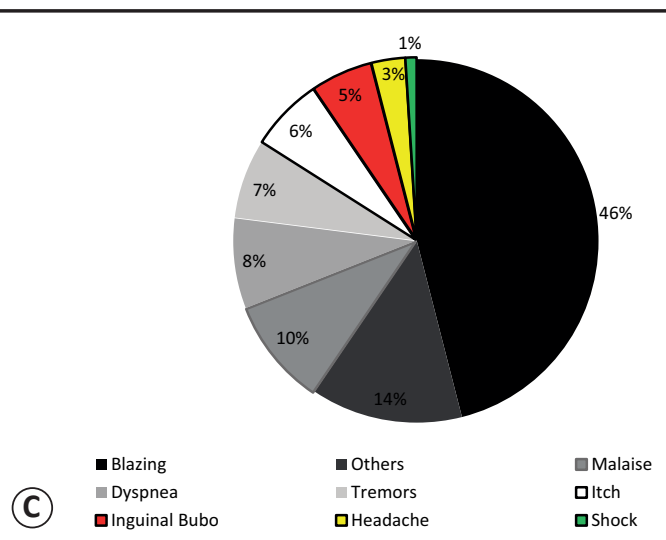

(D)

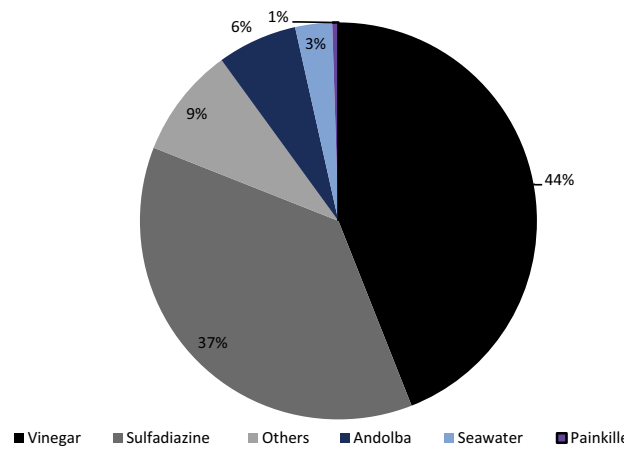

FIGURE 3. (A) Frequencies of envenomation events per human body region between January and May 2013. (B) Frequencies of envenomation events per human body region and age between January and May 2013. (C) Consequences, signs, and symptoms of Portuguese man-of-war envenomation events between January and May 2013. (D) Administered treatments after envenomation events.

walking on the sand. According to Haddad $\mathrm{Jr}^{11}$, a single contact with the tentacles can cause injuries in humans, as the differences in pressure cause nematocysts to disrupt and inoculate venom into the victim. The envenomation registry in São Luis indicated that the majority of lesions occurred on bathers' legs, hands, arms, and abdomens, whereas in children, adolescents, and youngsters, most injuries occurred on the hands as a result of intentional contact with the animal possessing the nematocysts. Most victims were envenomed only once, regardless of age. Peña and Cardell ${ }^{8}$ highlighted an important aspect common to all injuries caused by cnidarians: those who had been envenomed once might be more sensitive to venom in case of a second attack as a result of allergic processes with variable severity, including anaphylactic shock.

The main reported signs and symptoms were linear plaques with erythema/edema and intense burning pain in the areas of contact. Haddad Jr et al. ${ }^{1}$ explained that injuries caused by cnidarians did not truly involve burning, although the pain and skin appearance resemble those associated with sun or hot water burns ${ }^{1}$. According to Haddad $\mathrm{Jr}^{1}$ and Haddad Jr et al. ${ }^{14}$, the affected area should be washed with acetic acid and cold seawater, and an ice bag and cold seawater compress should be applied for 5-10 min. Painkillers are also recommended. The GBMar used topical sulfadiazine and Andolba ${ }^{\circledR}$ (benzocaine, menthol, benzoxiquine, and benzethonium chloride) as initial treatment measures. All patients were treated with acetic acid. Although authors have varying opinions on the use of acetic acid ${ }^{15}$, a majority do not recommend the use of freshwater because the osmotic difference would triggers the nematocysts. Haddad Jr et al. ${ }^{1}$ stated that either hot or cold water was an important step in attenuating the associated pain because the extreme temperature variation would have an anesthetic effect (cold or hot) ${ }^{1}$.

In conclusion, reports of envenomation events normally began in July and increases until January. Nevertheless, events occurred at the greatest frequency during December and January. The legs, hands, arms, and abdomen were most likely to be affected by contact with a Portuguese man-of-war. Although systemic manifestations were rare, intense local pain and inflammation were reported. Finally, self-applied treatments and those administered by lifeguards immediately after the incidents did not meet the current recommendations of the Health Ministry of Brazil.

\section{Ethical considerations}

The data presented in this research are a part of previous studies approved by the Ethics Committee of the Universidade Federal do Maranhão (CAAE 50673215.3.0000.5087/CEP 1.625.949 and CAAE 56407015.3.0000.5087/CEP 1.649.669).

\section{Acknowledgments}

The authors thank the Universidade Federal do Maranhão for technical support, Group of Firemen Maritime of Maranhão State (GBMar) and Municipal Secretary of Security and Citizenship (SEMUSC). 


\section{Conflicts of interest}

The authors declare that there is no conflict of interest.

\section{Financial support}

We thank the Fundação de Amparo à Pesquisa e Desenvolvimento Científico do Maranhão (FAPEMA) for providing financial (Process. PAEDT-01266/12).

\section{REFERENCES}

1. Haddad Jr V, Virga R, Bechara A, Silveira FL, Morandini AC. An outbreak of Portuguese man-of-war (Physalia physalis Linnaeus, 1758) envenoming in Southeastern Brazil. Rev Soc Bras Med Trop. 2013;46(5):641-44.

2. Neves RF, Amaral FD, Steiner AQ. Levantamento de registros dos acidentes com cnidários em algumas praias do litoral de Pernambuco (Brasil). Cien Saude Colet. 2007;12(1):231-37.

3. Bochner R, Struchiner CJ. Acidentes por animais peçonhentos e sistemas nacionais de informação. Cad Saude Publica. 2002;18(3):735-46.

4. Bardi J, Marques AC. Taxonomic redescription of the Portuguese man-of-war, Physalia physalis (Cnidaria, Hydrozoa, Siphonophorae, Cystonectae) from Brazil. Iheringia Série Zool. 2007;97(4):425-33.

5. Purcell JE. Jellyfish and ctenophore blooms coincide with human proliferations and environmental perturbations. Ann Rev Mar Sci. 2012;4(1):209-35.

6. Risk YJ, Cardoso JLC, Haddad Jr V. Envenoming caused by a Portuguese man-of-war (Physalia physalis) manifesting as purpuric papules. An Bras Dermatol. 2012;87(4):644-45.
7. Martínez Ramírez M, Villena Zálvez ME, Marín Jara I, Monedero La Orden J. Picadura por Carabela Portuguesa, una "medusa" algo especial. Rev Clin Med Fam. 2010;3(2):143-45.

8. Gutiérrez de la Peña J, Marqués Cardell C. Picaduras de medusas. Med Balear. 2012;27(2):45-48.

9. Moleiro S, Pereira A, Paiva Lopes MJ. Dermatose Marítima por Contato com uma Caravela-Portuguesa. Acta Med Port. 2013; 26(1):66-68.

10. Nastav B, Malej M, Malej Jr A, Malej A. Is it possible to determine the economic impact of jellyfish outbreaks on fisheries? A case study - Slovenia. Mediterr Mar Sci. 2013;14(1):214-23.

11. Haddad Jr V. Animais aquáticos de importância médica no Brasil. Rev Soc Bras Med Trop. 2003;36(5):591-97.

12. Duarte CM, Pitt KA, Lucas CH, Purcell JE, Uye SI, Robinson K, et al. Is global ocean sprawl a cause of jellyfish blooms? Front Ecol Environ. 2013;11(2):91-97.

13. Araújo Gonzalez R, Andreoli RV, Candido LA, Kayano MT, Souza RAF. A influência do evento El Niño - Oscilação Sul e Atlântico Equatorial na precipitação sobre as regiões norte e nordeste da América do Sul. Acta Amaz. 2013;43(4):469-80.

14. Haddad Jr V. Animais Aquáticos Potecialmente Perigosos do Brasil: Guia Médico e Biológico. $1^{\text {st }}$ edition. São Paulo: Editora Roca; 2009.

15. Ferrer L, Zaldua-Mendizabal N, del Campo A, Franco J, Mader J, Cotano U, et al. Protocolo operacional para el avistamiento y seguimiento del cnidario Physalia physalis (Carabela portuguesa) en el sureste del golfo de Bizkaia. RIM-Revista Investig Mar. 2013;20(7):89-101. 